\title{
Socio-technical Context of Market Gardening in the Ruzizi Plain in Eastern DRC: Constraints and Stakeholders' Strategies
}

\author{
Cadeau Rushigira, Germaine Furaha Mirindi, and Stany Vwima Ngezirabona
}

\section{ABSTRACT}

The Ruzizi Plain in general and the community of Ruzizi Plain in particular, although having considerable potential for the development of market gardening, do not manage to satisfy the demand for market garden produce in the main consumption area (Bukavu town), which continues largely to depend on Rwanda in its supplies. This situation suggests that market gardening in Ruzizi Plain is conducted in an environment marked by constraints. Some constraints relate to the actual process of production and marketing, and others are related to the quality requirements imposed by demand.

However, all these constraints are all triggers for the malfunction of market gardening sector. Faced with this, market gardeners adopt adaptive behavior to reduce and turn round these constraints. The choice of strategies by market gardeners depends on the perception of the constraints encountered and the resources available. Done on a sample of 81 market gardeners, this study enables to identify, based on an analysis of the technical context, the constraints of tomato and aubergine at Ruzizi Plain, and the strategies developed by market gardeners in the face of these constraints.

Keywords: Actor, Market gardening, Production system, Strategy.
Submitted : May 02, 2021

Published : May 23, 2021

ISSN: $2684-1827$

DOI: $10.24018 /$ ejfood.2021.3.3.295

Cadeau Rushigira *

Researcher at the Department of rural economics of UEA University, Panzi, Bukavu, The Democratic Republic of Congo.

(e-mail: cadeaurushigira@uea.ac.cd)

Germaine Furaha Mirindi

Professor and Researcher at the Department of rural economics of UEA University, Panzi, Bukavu, The Democratic Republic of Congo.

(e-mail: furaha.germaine@uea.ac.cd) Vwima Ngezirabona Stany

Professor and Researcher at the

Department of rural economics of UEA University, Panzi, Bukavu, The Democratic Republic of Congo.

(e-mail: svwima@uea.ac.cd)

*Corresponding Author

\section{INTRODUCTION}

The role of agriculture in development and poverty reduction in developing countries is crucial, given the number of full-time jobs it provides (around $70 \%$ of the working population), but also given the number of people who rely on it for part of their income [1], [2].

For its part, the Democratic Republic of Congo (DRC) is generally a country with enormous agricultural potential [3], and the province of South Kivu, in particular, is one of the provinces with high agricultural penetration in economic activities [4]. Made of mountains and plains, South Kivu offers favorable soil and climatic conditions for different types of crops. The practice of market gardening is becoming more and more popular in this area with the penetration of market garden products in the food habits of both the rural and urban population.

In general, the requirement for freshness favours the "periurban" origin for some market garden products such as leafy vegetables and temperate type vegetables [5]. However, the problems posed by rapid urbanization pose a serious threat to peri-urban agriculture and thus lead us to question its sustainability [5]-[7]. These different constraints on urban and peri-urban agriculture support our observation that some cities are supplied with market garden produce from the surrounding rural areas, as urban and peri-urban agriculture cannot meet all urban demand.

Muheme [8], believes that the adoption of market gardening by rural households in South Kivu is explained by the lack of state investment in agricultural activities. Initially in the Ruzizi Plain, market gardening was only practiced during the lean season (June, July, and August), but with the increase in demand, some farmers have specialized in market gardening and made it a permanent activity.

With a large land availability of about 80,000 ha [9] and an enormous irrigation potential, the Ruzizi Plain offer favourable conditions for the development of vegetable production. A great diversity of supply characterizes vegetable production in Ruzizi Plain. There are generally leafy vegetables (amaranth), fruit vegetables (tomatoes, aubergines) and root vegetables (carrots, onions). There is a noticeable specialization in the cultivation of tomatoes and aubergines. Vegetable production in Ruzizi plain has the characteristics of a peasant economy, with a non-mechanized production system and rudimentary cultivation techniques (the work on the land is essentially manual and all other operations physically involve the actors at all levels from sowing to harvesting).

The accessibility of the Ruzizi plain (crossed by the national road $n^{\circ} 5$ and located on the border with Rwanda), 
opens up an important supply area for market garden produce to the city of Bukavu (capital of the province of South Kivu) located "46.5 km away" and populated by approximately $1,012,053$ inhabitants.

Despite all the market gardening potential in Ruzizi Plain, market gardening has not been able to be develop and the city of Bukavu, the main consumption area, continues to depend on Rwanda for its supply of market gardening products. In this regard, it is necessary to assume that market gardeners in Ruzizi Plain operate in an environment full of constraints. In addition to production and marketing constraints, consumers impose on market gardener's quality constraints such as freshness, diversity, and quantity constraints, which is also a satisfaction variable. Market gardeners must be able to supply consumers regularly with sufficient quantities, otherwise they will turn to other sources of supply capable of meeting their demand. Faced with these constraints, market gardeners adopt an adaptive behaviour to reduce and circumvent them.

In view of the above, the purpose of this article is to identify, on the basis of a technical analysis, the constraints of market gardening (especially tomato and aubergine) in the Ruzizi Plain, and the strategies developed by the stakeholders in response to these constraints.

\section{MATERIALS AND METHODS}

\section{A. Study Area}

The Ruzizi plain is located in the east of the Democratic Republic of Congo, in the province of South Kivu. It includes part of the territory of Uvira and part of the territory of Walungu, along the Ruzizi River, which offers the region favourable conditions for agriculture.

The Ruzizi plain has a tropical climate with a dry tendency [10]. The annual rainfall reaches $1600 \mathrm{~mm}$ for 130-150 days of rain. The average temperature is $24{ }^{\circ} \mathrm{C}$. A dry period extends from May to October, during which two or three thunderstorms bring some rain; the wet period extends from November to May. The wind on the ground is very weak during the night and morning, but generally strengthens in the afternoon. It is also stronger in the dry season than in the rainy season [11]. The temperature in the Ruzizi Plain favours the cultivation of most crops, including aubergine and tomato, in the rainy season, when the average temperature is low. However, dry season cropping is very demanding in terms of water and yields are generally low due to the high temperature.

Agriculture is the main activity of the population of the Ruzizi plain. Food crops and market gardening constitute the bulk of agricultural activities [12]. Market gardening in the Ruzizi plain occupies 2,866.82 ha out of 80,000 ha of available arable land, i.e., about $3.60 \%$ of the area. These figures confirm the importance of market gardening in the Ruzizi plain, as generally market gardening does not require very large areas $(2,866.82$ ha for market gardening is already significant). Alongside agriculture, extensive cattle, pig, goat, and poultry farming is carried out [13]. Agriculture in the Ruzizi Plain is generally practiced in season A and B. Some crops are grown in the off-season (season C), and other crops (vegetables) are grown on a regular basis (all year round) in areas accessible to irrigation water.
Market gardening is practised throughout the Ruzizi plain, but at varying intensities depending on proximity to a potential consumption area, but also on whether the soil and conditions (e.g., irrigation) are favourable to market gardening. The market garden crops grown on the Ruzizi plain are aubergine, cabbage, tomato, amaranth, squash, and onion. Of these crops, tomato, aubergine and onion are important in terms of quantity produced, number of market gardeners and area sown [13].

\section{B. Data Collection and Analysis}

The methodology adopted for this paper uses a combined approach that applies the tools of qualitative and quantitative research in parallel. Based on empirical analysis and an inductive approach, this study requires relevant primary and secondary data and their appropriate processing based on methodological interactionism.

The secondary data were collected through documentation on the subject matter, but also through the exploitation of various official reports from IPAPEL (Provincial Inspection of Agriculture, Fisheries and Livestock). The field surveys, on the other hand, provided us with primary data. The collection of primary data was carried out in two phases: an exploratory phase and a survey phase.

Since we did not have a list without omission or repetition of all the market gardeners in Ruzizi plain, and the probability of a market gardener being drawn was not known, it was difficult to use probability or random sampling methods. Thus, empirical sampling methods were used in this study, and the interval sampling method was employed. This method consisted of surveying 1 out of every 5 farmers encountered in each market garden site.

We selected three market gardening sites where market gardening is very intense, and the distribution of respondents was done by quota according to the number of market gardeners available in each site. The statistics collected by the agricultural service showed 270 market gardeners on all the sites. Considering a sampling rate of $30 \%$, we obtained a sample size of 81 market gardeners spread over the three selected sites. Based on the proportion represented by each site.

Having noted that the sites of KABOYA, RUGENGE and CIRIRA contain more market gardeners than all the other sites, with $11.9 \%, 18.9 \%$ and $25.6 \%$ of market gardeners respectively, we chose to survey the market gardeners in these three sites.

The information collected through the survey was analysed using computer tools. We used spreadsheets and statistical software for data processing, encoding and analysis. Thus, Ms Excel helped us to analyse the survey data, SPSS helped us to analyse the data. The tables obtained from SPSS were then brought back into Excel for formatting. Ms Excel also allowed us to generate graphs. To analyse the data, we used a statistical approach that allowed us to identify and measure trends.

The constraints of the sector and the strategies of the actors (market gardeners) will be perceived on the basis of three key dimensions of the sector (technical, economic and institutional) as represented in Fig. 1. For the purpose of this paper, only the technical dimension will be addressed. 


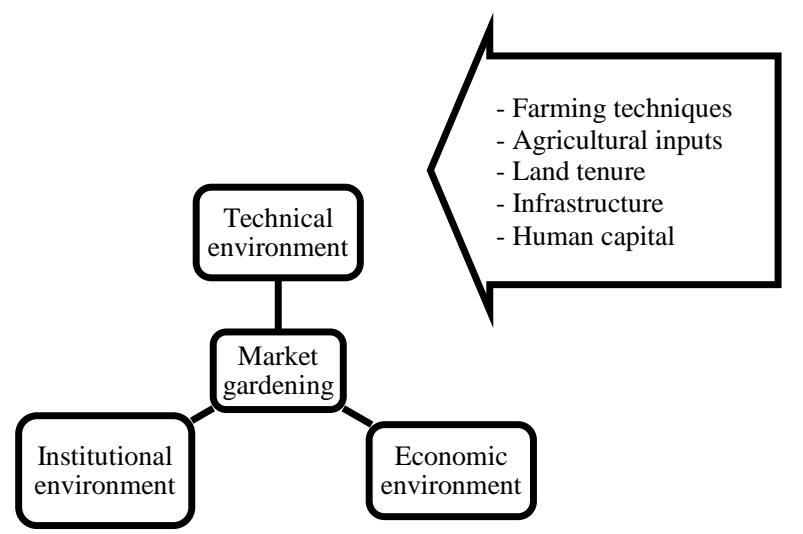

Fig.1. Elements of market gardening study.

\section{RESULTS AND DISCUSSION}

\section{A. Profile and Characteristics of Market Gardeners}

Although some authors [14], [15] have observed a certain feminisation of market gardening, the trend is quite the opposite in the Ruzizi Plain, where men are more present than women. $74.1 \%$ of the respondents were men, compared to only $25.9 \%$ of women. As market gardening is a marketoriented activity, i.e., one that offers cash income, the high representation of men is justified, as the literature argues that in Africa, men are more oriented towards crops that offer cash income, while women are involved in subsistence farming [16]-[18]. According to interviews with market gardeners, unemployment in Ruzizi Plain is at a very high level. To meet daily household needs, men engage in activities that can provide them with cash income. For example, they explain that growing tomatoes and aubergines provides a cash income every three months, but also that market gardening does not require large investments. On the other hand, women are reluctant to grow these crops because of the technical requirements (regular maintenance) that incur costs, while they generally have low financial capacities.

Married people and widows represent $67.9 \%$ and $18.5 \%$ of our sample. $66.7 \%$ of our respondents are heads of household. As they are looking for monetary income to meet the needs of the households they head, it is logical that they are sufficiently represented in market gardening. Single people, on the other hand, represent only $13.6 \%$. When interviewed about their motivations for practicing market gardening, some young single people said they were looking for funds to finance their marriage, while others confided that they were looking for financial capital to start a business or provide transport services (motorbikes) and others felt that they were looking for income for various investments (to finance their studies, to finance their travel, etc.). This result shows that, in addition to its permanent nature, market gardening also has the characteristics of a transitional activity for a category of people, enabling them to realise their ambitions later on.

Market gardeners in the Ruzizi Plain are generally less educated. In our sample, more than three quarters, or about $82.7 \%$ of the market gardeners, have not attained secondary school education.

The age of the market gardeners ranged from 17 to 67 years, with an average of 39.9 years. $54.4 \%$ of the market gardeners were over 40 years old, compared to only $45.6 \%$ of the market gardeners under 40 years old. These results are in contrast to those of Kanda et al [6], who found in their study that the majority of market gardeners at the scale of $65 \%$ were young people under 40 years of age.

The results of this study show that $72.8 \%$ of market gardeners in the Ruzizi Plain have another activity in addition to market gardening, compared to only $27.2 \%$ of market gardeners who do not associate another activity with market gardening. Market gardeners, like any other farmer for that matter, being homo economicus, diversification of activities and/or crops is a normal behaviour in an activity as risky as agriculture. These results are therefore in line with Fraval's [19] thesis that diversification of activities appears to be a strategy of rural African farmers in the face of the risks and uncertainties very present in agriculture. Still in the strategy of market gardeners in the face of the many risks of agriculture, we observed that most market gardeners have several fields scattered in the perimeters, because sometimes diseases and pests appear in some sites and not in others (which makes yields sometimes good in some sites and not in others). In the market gardening sites studied, the market gardeners have an average of two fields for market gardening.

We distinguished three categories of market gardeners for the cultivation of tomato and aubergine: market gardeners producing only tomato, market gardeners producing only aubergine and market gardeners producing both tomato and aubergine.

It should also be noted that $19.8 \%$ of market gardeners surveyed in Ruzizi Plain are Rwandan. The only reason they gave for crossing the border was access to land. As land management is very rigorous and extremely structured in Rwanda, access to land is therefore very limited. Furthermore, in the Ruzizi Plain, access to land is not too structured and therefore easy. "... you only need to have a little money to access the land', they say.

\section{B. Technical Context of Market Gardening}

\section{1) Production System}

The possibility of a market gardener owning several fields led us to identify three cropping systems among market gardeners in the Ruzizi Plain. We therefore identified: market gardeners who produce in monoculture only in all their fields, those who produce in crop association in all their fields and finally, those who produce in monoculture in some fields and in crop association in others.

The reason for the high dominance of intercropping among market gardeners is that tomato and aubergine require large spacings ( $1 \mathrm{~m}$ between two rows and $0.5 \mathrm{~m}$ between two plants). In order to recover this space considered "lost", the market gardeners prefer to put another crop between the spacings. The main crops associated with tomato and aubergine in Ruzizi Plain are maize and beans. While beans are more associated with aubergine, maize is more associated with tomato. The preference for the association of maize with tomato is explained by the fact that tomato growers apply the mulching technique to preserve soil moisture. Thus, the stalks and leaves of maize after harvesting are used as mulch by the market gardeners.

Tomatoes in Ruzizi Plain are produced in an irrigated system or in the marshes near the Luvimvi River, while aubergines are produced either in the marshes or in a rainfed system. Tomato irrigation is done by hand watering. 
TABLE I: TYPE OF MARKET GARDENING

\begin{tabular}{lcccc}
\hline \hline \multirow{2}{*}{ Crops } & \multicolumn{3}{c}{ Type of market gardening } & \multirow{2}{*}{ Total } \\
\cline { 2 - 4 } & Irrigated & Marsh & Rainfed & \\
\hline Aubergine & 0 & 23.1 & 76.9 & $100 \%$ \\
Tomato & 81.2 & 18.8 & 0 & $100 \%$ \\
\hline \hline
\end{tabular}

The farmers explained that they prefer to produce tomatoes under an irrigated system, because they will at least have control over the amount of water to give to the plant as needed. The tomato needs more water in its early stages, but when it is already bearing fruit, it does not need more water. The abundance of water at that stage may cause the fruit to rot. On the other hand, aubergines are produced more in rainfed systems $(76.9 \%)$ because of the difficulty of manually watering aubergines due to the size of their leaves. This is why some people decide to produce it in the marshes near the river to take advantage of the soil moisture. This situation explains the seasonality of aubergine production (produced only during the rainy season) and the punctuality of tomato production.

In this regard, it should be noted that access to water is one of the major constraints to market gardening in Ruzizi Pain, which sometimes leads to low yields. During the interviews, market gardeners told us that when the rains are scarce, the humidity in the marshes tends to disappear and the water table decreases significantly, which leads to a lack of water in the wells. However, this phenomenon is becoming more and more frequent in Ruzizi Plain. Faced with this situation, $60.5 \%$ of the market gardeners interviewed confirmed that they had problems accessing water (either because the river is too far away to get water, or because the wells do not provide enough water for watering, or because the wells are rare), as opposed to only $39.5 \%$ of the market gardeners who said they had no problems. In response to the constraint of access to water, some market gardeners opt to reduce their market gardening activities, while others increase the depth of their wells in an attempt to reach the water table.

The transplanting technique is practiced on all the farms surveyed, $83 \%$ of which use line transplanting and $17 \%$ use bulk transplanting.

\section{2) Description and the Land Situation Analysis}

Land is an important element in agricultural production. It is discussed here as a support for productive activity, and we will focus on individual management of agricultural land. Ndiaye [20] defines individual management of agricultukel land as all decisions and actions affecting the land factor in the appropriation and use as a productive resource.

In Ruzizi Plain, several modes of appropriation or access to land exist for market gardening. These are: renting, buying, inheriting, and giving. However, it should be noted that the same market gardener can use several modes of access at the same time to try to increase his area. We have, in fact, grouped the different modes of access to land into the tenure mode. In the direct tenure mode, we have included purchase and inheritance, and in the indirect tenure mode, we have included rental and donation. Thus, we are left with three possibilities according to Fig. 2: market gardeners using direct tenure only, market gardeners using indirect tenure only and market gardeners using both tenure types simultaneously.

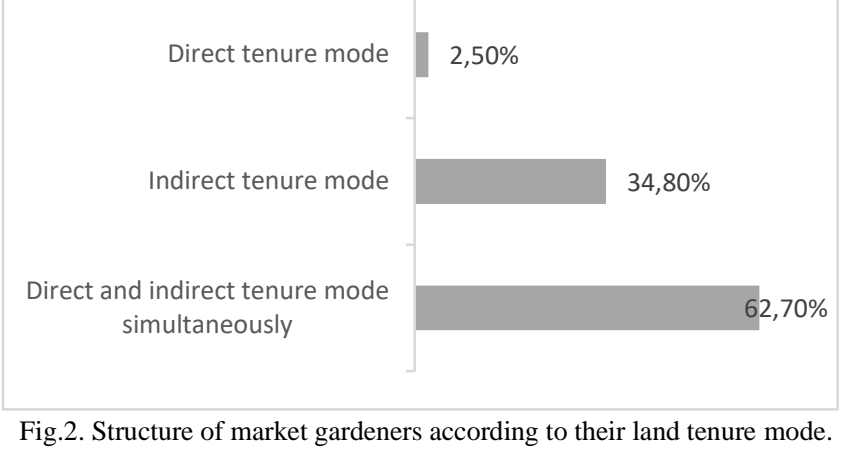

Fig.2. Structure of market gardeners according to their land tenure mode.

The study found that renting is used as a means of accessing to land by almost $97 \%$ of the market gardeners in Ruzizi Plain. Renting has been identified by several authors [14], [21], as the most frequent mode of access to land in market gardening. All tenant farmers told us that they are in the fermage system, in which they pay an annuity (in money) to the owner of the land for the duration of one year. This situation leads to a high degree of land monetisation in market gardening in Ruzizi Plain, as observed by Omrane [22] in a study on access to land in Madagascar. On the other hand, purchase is the least popular mode of access to land among market gardeners, yet $86.4 \%$ of the market gardeners we interviewed confirmed that it is easy to find agricultural land to buy in Ruzizi Plain. After our interviews with the leaders of the market gardening groups, it became clear that this lack of recourse to purchase is explained by the poverty in the area.

$100 \%$ of the market gardeners confirmed that they did not have official land titles. Only a few market gardeners who had bought land said that they had a simple deed of recognition. In contrast, for those who rented the land, the contract was verbal and based on trust. These results are in line with the FAO [14] assertion that market gardeners operate the land under various arrangements without any formal title.

The survey results revealed a modest total holding size for market gardening in Ruzizi Palin. For example, in Cirira, the average area under tomato is 0.43 ha per farmer. In contrast, the average area under tomato in Kaboya and Rugenge is 0.32 and 0.36 ha per farmer respectively. For aubergine, the average area is 0.055 ha in Cirira, 0.18 ha in Kaboya and 0.2 ha in Rugenge.

\section{3) Characteristics of Agricultural Inputs and Tools}

\section{Agricultural Inputs}

Market gardeners in Ruzizi Plain use two types of seed. Improved variety seeds (from imports and sold in agroveterinary pharmacies or shops) and traditional varieties (called old varieties by the farmers). The vegetative cycle of the seeds used is 4 months for both crops. The market gardeners felt that the problem of seed availability does not arise in Ruzizi Plain because of its proximity to Rwanda and Burundi, where the agricultural input chain is well organised, but that access remains problematic due to the lack of financial means of the market gardeners.

Three modes of seed supply were identified during the surveys. These are purchase, donation, and reserve from previous production. The results of the surveys indicate that $60.7 \%$ of the market gardeners who buy their seeds cross the border into Rwanda or Burundi to purchase them. When asked about this, some of these farmers simply said that they 
hope to find good quality seeds in Rwanda or Burundi, others felt that there they have a choice of several varieties whereas in Ruzizi Plain the choice is limited. But also, the price in Rwanda or Burundi is a little lower than in Ruzizi Plain. On the other hand, $39.3 \%$ of market gardeners who buy seeds prefer to do so locally. For some market gardeners, the reason for buying seeds locally is the countless hassles they face when crossing the Congolese border. For others, the social relations they have with local seed sellers are the cause.

In terms of the quantities of seed used per ha, the following table provides information.

TABLE II: DESCRIPTIVE STATISTICS ON QUANTITIES OF SEED USED

\begin{tabular}{ccccc}
\hline \hline \multicolumn{1}{c}{ Crops } & Mean & St.dev & Min & Max \\
\hline $\begin{array}{c}\text { Aubergine seed } \\
(\mathrm{Kg} / \mathrm{ha}) \\
\begin{array}{c}\text { Tomato seed } \\
(\mathrm{Kg} / \mathrm{ha})\end{array}\end{array}$ & 74.2 & 10.6 & 48 & 96 \\
\hline \hline
\end{tabular}

The above table shows that market gardeners in Ruzizi Plain use an average of $5.3 \mathrm{~kg}$ of tomato seed per ha and $74.2 \mathrm{~kg}$ of aubergine seed per ha.

The information on the amount of seed used clearly shows that the vegetable farmers are not better informed or trained on proper cultivation techniques. In view of the above, there is still a problem of use. For one hectare, it is generally recommended to use between $250 \mathrm{~g}$ and $500 \mathrm{~g}$ of tomato seeds depending on the variety [23], [24]. Tomato farmers in the Ruzizi Plain use ten times more seed than the recommended standard.

At the end of our study, we found that the majority of market gardeners in the Ruzizi Plain use fertiliser and plant protection products in their farms. $90 \%$ of aubergine producers use fertiliser, compared to only $10 \%$ of producers who do not use fertiliser. The market gardeners who do not use fertiliser nevertheless recognised the importance of fertiliser for the plant, because they felt that their production was very poor compared to those who use it.

Chemical fertiliser is the most common fertiliser used by farmers in Ruzizi Plain. In contrast, the use of organic fertiliser is not widespread in market gardening. Nevertheless, some farmers leave some plant residues to decompose in the fields to benefit from humus. The results of the surveys allowed us to identify three types of fertiliser used by market gardeners in our study area. These are DAP, NPK and Urea. Most of the market gardeners we met did not seem to know the function of each type of fertilizer for the plant, as they felt that the most important thing was to have only applied the fertilizer, regardless of the quantity or type of fertilizer used. Beyond the problem of access to fertiliser, as $66.7 \%$ of market gardeners stated that they do not have easy access to fertiliser due to their low financial capacity, there is a problem of knowledge or information. There is also a problem of poor fertiliser use. According to the FAO [25], the recommended fertiliser dose for aubergine production, for example, is $200 \mathrm{~kg} / \mathrm{ha}$ of urea and $400 \mathrm{~kg}$ of DAP fertiliser, whereas on average market gardeners use $60 \mathrm{~kg}$ of urea and $60 \mathrm{~kg}$ of DAP per ha to produce aubergine. According to the INSID synthesis [26], the absence of a technical reference for fertilisation and the low level of experimentation, combined with the economic constraints of access to fertilisers, are at the root of an inefficient use.

\section{b) Agricultural Tools}

The study shows that market gardening in the Ruzizi Plain is not mechanised. The tools used in production are manual. Faced with this constraint of non-mechanisation in market gardening, market gardeners adopt different strategies. Since all activities are manual, i.e., require physical strength, market gardeners opt for areas that are consistent with their physical strength or with the strength they are able to mobilise. For example, during our interviews, when we asked some market gardeners if they would like to increase their cultivated area, the answer was simply: "I do not have enough strength to cultivate large areas".

It should also be noted that some of the equipment used in market gardening in Ruzizi Plain does not belong to the farmer but to the labour force. To be employed on a farm in the spraying phase of plant protection products, for example, the person must have his own sprayer. He/she must have his/her own hoe if it is the soil preparation phase for example.

Tomato storage and preservation tools are a major challenge for market gardeners in the Ruzizi plain. According to market gardeners, storage and preservation equipment is one of the main constraints to market garden production in Ruzizi Plain.

For tomatoes, the storage materials used are used 20 liters cans with an enlarged opening in which tomatoes are stacked in an average of 10 layers, and which do not take into account the temperature requirements. These cans contain an average of $12 \mathrm{~kg}$ of tomatoes. These storage conditions are contrary to the recommendation of Courchinoux [23], according to which, "in order to limit transport losses, it is recommended to pack the fruit in rigid boxes, with a maximum of 5 to 6 layers of fruit".

The inadequate storage and conservation conditions for tomatoes in the Ruzizi Plain inflict considerable losses on market gardeners. To get around this problem, most market gardeners prefer to sell their produce directly in the field, to avoid the storage and transport process. Other growers even decide to sell all the production still standing. When selling the produce on a local market, the farmer picks before it is fully ripe, when the product has reached the pink stage.

Aubergine, given its nature and condition, does not pose too many problems related to preservation and storage. It can be stored in bags.

\section{4) Labour Force Analysis}

In the Ruzizi Plain, only two types of labour were observed in our surveys: family labour and wage labour. Some market gardeners combine family labour with wage labour and others use only family labour. As market gardening in Ruzizi Plain is not mechanised, it involves manual cultivation techniques that greatly increase labour requirements, as can be seen in the following table. 
TABLE III: NUMBER OF MAN-DAYS PER PRODUCTION PHASE

\begin{tabular}{lcc}
\hline \hline Production phase & $\begin{array}{c}\text { Number man-day } \\
\text { per ha for tomato } \\
\text { production }\end{array}$ & $\begin{array}{c}\text { Number man-day per } \\
\text { ha for aubergine } \\
\text { production }\end{array}$ \\
\hline Soil preparation & 48 & 48 \\
Nursery & 4 & 3 \\
Transplantation & 16 & 12 \\
Watering & 64 & 0 \\
Bed formation & 2 & 2 \\
3 Weeding & 12 & 4 \\
Fertiliser application & 24 & 12 \\
Spraying of plant & 16 & 14 \\
protection products & & 4 \\
Harvesting & 8 & 2 \\
Transport & 0 & 101 \\
\hline Total & 194 & \\
\hline \hline
\end{tabular}

To produce tomato and aubergine on 1 ha, market gardeners in the Ruzizi Plain use an average of 194 and 101 man-days respectively to carry out the various tasks in the entire production process. All the results on the quantification of labour sufficiently show how great the need for labour in market gardening in Ruzizi Plain is. In this regard, labour poses a great challenge to the vegetable growers.

Faced with the huge need for labour, the market gardeners felt that the strategy to reduce the cost of labour is to resort to family labour, which they consider to be unpaid labour. Thus, the results of our surveys indicate that to produce tomato and aubergine in Ruzizi Plain on 1 ha, family labour performs tasks that would be carried out by 76.5 and 44.5 man-days respectively. Family labour thus represents $39.4 \%$ of the total labour force for tomato production and $42.4 \%$ of the total labour force for aubergine production.

Considering 4 categories of family labour: young-boy family labour (under 15 years), young-girl family labour (under 15 years), male family labour (over 16 years) and female family labour (over 16 years), there is a certain distribution of work by category.

TABLE IV: STRUCTURE OF THE FAMILY LABOUR FORCE ACCORDING TO THE PHASES OF PRODUCTION

\begin{tabular}{lcccc}
\hline \multicolumn{5}{c}{ THE PHASES OF PRODUCTION } \\
Production phase & $\begin{array}{c}\text { young- } \\
\text { boy } \\
\text { labour }\end{array}$ & $\begin{array}{c}\text { young- } \\
\text { girl } \\
\text { labour }\end{array}$ & $\begin{array}{c}\text { Male } \\
\text { labour }\end{array}$ & $\begin{array}{c}\text { Female } \\
\text { labour }\end{array}$ \\
\hline Soil preparation & & & & \\
Nursery & & & \\
Transplantation & & & \\
Watering & & & \\
Bed formation & & & \\
3 Weeding & & & \\
Fertiliser application & & & \\
Spraying of plant \\
protection products \\
Harvesting \\
Transport
\end{tabular}

is found when a labour category performs less than $25 \%$ of the work. The table shows that young family workers (girls and boys) are much more involved in the transplanting, watering, and harvesting phases. The market gardeners felt that the activities in these three phases require sufficient labour, although they do not require much physical strength. Thus, they prefer not to incur costs for these phases because they feel that their children are capable of performing these activities.

The above table also shows a certain division of labour by gender as mentioned by Brossier, Devèze, \& Kleene [27]. Women are more involved in soil preparation, transplanting, weeding, hoeing, and harvesting, while men are more involved in nursery work, watering, forming beds, applying fertilisers and plant protection products, and transporting the crop.

\section{Identification of Constraints and Strategies}

Following the analysis of the technical environment of market gardening in the Ruzizi Plain, the following constraints were identified on the basis of the factors (indicators) shown in the following figure. The farmers' decisional choice to adapt to the context according to the theoretical logic of adaptive behaviour was also identified.

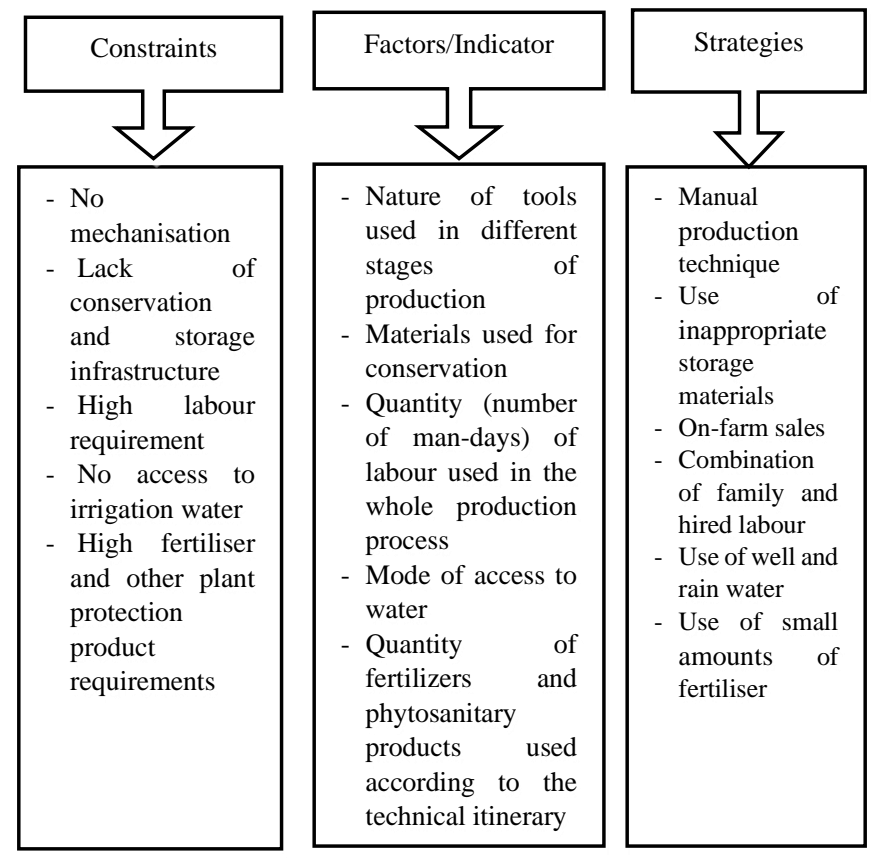

Fig. 3. Identification of technical constraints and strategies of market gardeners.

\section{CONCLUSION}

To conclude this article, the objective of which was to identify the various constraints faced by market gardeners in the technical environment in the Ruzizi Plain in east of DRC (mainly tomato and aubergine) and the strategies developed to overcome them, it is necessary to recall that the analysis of the various components of the technical context (cropping system, land situation, agricultural inputs, labour) allowed us to identify these constraints thanks to a certain number of indicators. The different decisions for any action to be taken by the market gardeners in the technical environment always 
refer to the objective of maximising the production level. However, the different constraints lead the market gardeners to reframe their objectives according to the constraints and means at their disposal.

Thus, the nature of the tools used in the different production phases enabled us to identify the problem linked to mechanisation. Faced with this, the market gardeners opt for manual techniques despite the negative repercussions on the level of yield. The materials used for preservation highlight the problem of inadequate storage and preservation infrastructure, which encourages market gardeners to sell their produce on the farm despite the impact on the selling price. The amount of labour required for production confirms a high demand for labour. To meet this requirement, some market gardeners reduce the area, while others opt not to use family labour. The quantity of inputs used is a problem related to access and use, but also to the high input requirements of the crops. To this end, strategies of area reduction and use of accessible quantities are used.

\section{REFERENCES}

[1] BAD, Stratégies Du Secteur de l'agriculture 2010-2014, 2010 https://www.afdb.org/fileadmin/uploads/afdb/Documents/Policy-.

[2] Banque Mondiale, Rapport Sur Le Développement Dans Le Monde: Agriculture Au Service de Développement. Washigton DC, 2008.

[3] Ministère de l'agriculture Pêche et élevage - RDC, Note de Politique Agricole. Kinshasa, 2009.

[4] PNUD, Province Du Sud-Kivu : Profil Resumé, Pauvreté et Conditions de Vie Des Ménages, 2009.

[5] P. Moustier and J. Pages, "Le Péri-Urbain En Afrique : Une Agriculture En Marge ?" Economie rurale 241: 48-55, 1997.

[6] M. Kanda, W. Kpérkouma, K. Batawila, D-B. Gbandi, A. Ahanchedé, K. Akpagana, "Le Maraîchage Périurbain à Lomé: Pratiques Culturales, Risques Sanitaires et Dynamiques Spatiales." Cahiers Agricultures 18(4): 356-63, 2009.

[7] P. Moustier, and O. David, Etudes de Cas de La Dynamique Du Maraichage Péri-Urbain En Afrique Sub-Saharienne. Montpellier, 1996.

[8] G.B. Muheme, Comprendre l'économie Informelle: Sociologie, Économie et Histoire de La Filière Mboga. Bruylant-A. Louvain-laNeuve, 1996.

[9] D. De Failly, "L'economie Du Sud-Kivu 1990-2000: Mutations Profondes Cachees Par Une Panne." L'Afrique des grands lacs, annuaire 1999-2000: 163-92, 2000.

[10] Unité de pilotage du processus DSRP, Monographie de La Province Du Sud-Kivu. Kinshasa, 2005.

[11] CTB PAIDECO Uvira, Monographie Du Territoire et de La Cité d'Uvira. Uvira, 2009.

[12] Inspection provinciale de l'agriculture pêche et élevage (IPAPEL-SudKivu), Rapport Annuel 2014, 2015.

[13] Inspection provinciale de l'agriculture pêche et élevage (IPAPEL-SudKivu), Rapport Annuel 2017, 2018.

[14] FAO, Pour Des Villes plus Vertes En Afrique: Premier Rapport d'étape Sur l'horticulture Urbaine et Péri Urbaine. Rome, 2012.

[15] A. Mfoukou-Ntsakala, M. Bitémo, N. Speybroeck, G. Van Huylenbroeck and E. Thys, Agriculture urbaine et subsistance des ménages dans une zone de post-conflit en Afrique centrale. Biotechnol. Agron. Soc. Env. 10, 237-249, 2006.

[16] A. Bopda, Le secteur vivrier Sud-Camerounais face à la crise de l'économie cacaoyère. Trav. l'Institut Géographie Reims 83-84, 109$122,1993$.

[17] D. Oumar Ismaila, «Engagement féminin et agriculture vivrière familiale au Sénégal, in: Genre Familial et Agriculture Paysanne: Regard Nord-Sud. Université de Toulouse II, 2012.

[18] D. Wartena, Marchandisation et production agricole féminine, in: Daane, J., Breusers, M., Frederiks, E. (Eds.), Dynamique Paysanne Sur Le Plateau Adja Du Bénin. Paris, pp. 116-151, 1997.

[19] P. Fraval, Éléments pour l'analyse économique des filières agricoles en Afrique sub-saharienne, 2000.

[20] A. Ndiaye, Statut foncier et gestion des terres agricoles au Sénégal. Université de Montpellier I, 1985.
[21] N. Kasanda Mukendi, A. Mushagalusa Balasha, J.H. Kitsali, J. Nkulu Mwine Fyama, and J. Bogaert, Maraichage périurbain à Lubumbashi : modes d'accès à la terre et gestion des superficies agricoles. Int. J. Innov. Appl. Stud. 14, 27-36, 2016.

[22] M. Omrane, Accès à la terre, dynamique démographique et ancestralité à Madagascar, L'Harmatta. ed. Paris, 2008.

[23] J.P. Courchinoux, Fiche technique Tomate, 2008.

[24] FAO-CDH, Techniques de production de semences de tomate au Sénégal. Dakar, 2012.

[25] FAO, Utilisation des engrais par culture en Algérie, Service de la gestion des terres et de la nutrition des plantes, Division de la mise en valeur des terres et des eaux. Rome, 2005.

[26] INSID, Note de synthèse sur les actions réalisées par l'INSID dans le cadre de la fertilisation, 2009.

[27] J. Brossier, J.C. Devèze and P. Kleene, Qu'es-ce que l'exploitation agricole familiale en Afrique?, in: Exploitations Agricoles Familiales En Afrique de l'Ouest et Du Centre. Versailles Cedex, pp. 73-86., 2007. 